\title{
EFEKTIVITAS PEMBELAJARAN PENDIDIKAN KARAKTER DENGAN MENGGUNAKAN MEDIA KARTUN DAN GAMBAR TOKOH LOKAL PADA PESERTA DIDIK SD NEGERI BIBISLUHUR 1 SURAKARTA
}

\author{
Sarafuddin \\ Staf Pengajar Prodi PGSD FKIP UNISRI \\ Sarafuddinmi11@gmail.com
}

\begin{abstract}
Info Artikel
Masuk: 1 Juli 2020

Revisi: 27 Juli 2020

Diterima: 4 Agustus 2020

Terbit: 15 Agustus 2020

Keywords:

arranged by alphabetically and contain three to five words/phrases separated with coma.
\end{abstract}

Kata kunci:

Pembelajaran, Pendidikan Karakter, Media Kartun, Gambar Tokoh Lokal.

$$
\begin{aligned}
& \text { P-ISSN : 2550-0171 } \\
& \text { E-ISSN : 2580-5819 } \\
& \text { DOI }: 10.33061
\end{aligned}
$$

\begin{abstract}
Write your abstract here. Abstract contains a brieft introduction to the problem, objective of manuscript, research methods and a brieft summary of result. Abstract is single-spaced typed in English maximum 150 words. Written with Trebuchet MS (10 Pt) Italic.
\end{abstract}

\begin{abstract}
Abstrak
Penelitian ini bertujuan untuk mendapatkan gambaran yang jelas tentang: (1) Media pembelajaran yang digunakan guru dalam pembelajaran pendidikan karakter pada peserta didik SD Negeri Bibisluhur 1 Surakarta, dan (2) Keefektivan media kartun dan gambar tokoh lokal dalam meningkatkan pembelajaran pendidikan karakter di SD Negeri Bibisluhur 1 Surakarta.

Penelitian ini termasuk penelitian deskriptif kualitatif, dengan strategi studi kasus terpancang tunggal. Data diperoleh dari: (1) Tempat dan peristiwa yaitu kegiatan pembelajaran di SD Negeri Bibisluhur 1 Surakarta. Dari sumber data ini akan diperoleh informasi tentang efektivitas pembelajaran pendidikan karakter dengan menggunakan media kartun dan gambar tokoh lokal; (2) Dokumen, yaitu dokumen berupa buku-buku pelajaran, media pembelajaran yang digunakan oleh guru, dan laporan hasil evaluasi belajar peserta didik, dan (3) Informan, yaitu terdiri dari guru dan peserta didik kelas 5 SD Negeri Bibisluhur 1 Surakarta. Untuk memperoleh data dilakukan dengan: (1) Observasi; (2) Analisis dokumen, dan (3) Wawancara mendalam. Dalam upaya memperoleh validitas data dilakukan dengan trianggulasi data/sumber dan metode. Teknik analisis data dilakukan secara bersama antara komponen analisis, yaitu reduksi data, sajian data dan verifikasi atau penarikan simpulan dengan pengumpulan data secara interaktif menggunakan model siklus. Target luaran penelitian ini antara lain; (1) Menambah wawasan guru dalam memilih media pelajaran yang berbasis pendidikan karakter serta dapat memahamkan peserta didik tentang kearifan lokal; (2) Tersedia seperangkat media pembelajaran pendidikan karakter yang bersumber dari riwayat tokoh lokal.
\end{abstract}




\section{PENDAHULUAN}

Berpijak pada kebijakan pemerintah Indonesia di bidang pendidikan kelihatannya belum mencapai target maksimal sebagaimana yang diamanat di dalam UUD 1945 atau bisa dikatakan masih pada tahap mencari bentuk atau pola yang tepat untuk mencapai tujuan pendidikan nasional yang telah ditetapkan. Realita ini dibuktikan dengan sering terjadinya pergantian kurikulum yang berlaku secara universal pada setiap jenjang pendidikan. Padahal di setiap pergantian kurikulum tentunya melahirkan berbagai macam kebijakan yang bersifat sentralistik dan berpengaruh pada tatanan sistem pembelajaran di setiap jenjang pendidikan. Kurikulum 2013 yang memberikan penekanan untuk mengoptimalkan aspek kompetensi sikap, keterampilan, dan pengetahuan. Kompetensi tersebut dikembangkan melalui pembelajaran tematik integratif yang dilaksanakan dengan pendekatan sains.

Kenyataan ini dapat dikatakan bahwa belum semua guru sekolah dasar memiliki pengalaman mengajar menggunakan pendekatan pembelajaran tematik integratif. Apalagi membuat variasi pembelajaran dengan memanfaatkan media pembelajaran berbasis gambar tokoh lokal dan menyisipkan karakter tokoh lokal dalam setiap pembelajaran sebagai upaya menanamkan pendidikan karakter pada peserta didik di tingkat sekolah dasar. Profil dan karakter tokoh lokal sangat penting diajarkan karena dapat menumbuhkan sikap, karakter baik, dan kemandirian peserta didik sebagaimana kepribadian seorang tokoh.

Di satu sisi dapat dipahami bahwa laju perkembangan ilmu dan tekonologi begitu pesat dan begitu luasnya sehingga dapat berpengaruh terhadap perubahan sikap mental dan pola belajar anak didik. Berdasarkan realita ini muncul pertanyaan media pembelajaran apakah yang digunakan guru dalam pembelajaran pendidikan karakter pada peserta didik SD Negeri Bibisluhur 1 Surakarta tahun 2019?, dan bagaimana keefektivan media kartun dan gambar tokoh lokal dalam meningkatkan pembelajaran pendidikan karakter di SD Negeri Bibisluhur 1 Surakarta tahun 2019 ?.

\section{LUARAN PENELITIAN}

Dari hasil penelitian ini diharapkan dapat memberikan sumbangan pemikiran tentang pentingnya pemahaman guru terhadap efektivitas pembelajaran pendidikan karakter pada peserta didik dengan menggunakan 2 media pembelajaran yang berbeda, yaitu media kartun dan media gambar tokoh lokal. Setelah dilaksanakan penelitian yang mendalam, maka luaran yang diinginkan adalah menambah wawasan guru dalam memilih media pelajaran yang berbasis pendidikan karakter serta dapat memahamkan peserta didik tentang kearifan lokal. Tersedia seperangkat media pembelajaran pendidikan karakter yang bersumber dari riwayat tokoh lokal. 


\section{KAJIAN TEORI}

Menurut pendapat Abdul Majid (2013: 5) bahwa pembelajaran adalah suatu konsep dari dua dimensi kegiatan (belajar dan mengajar) yang harus direncanakan dan diaktualisasikan, serta diarahkan pada pencapaian tujuan atau penguasaan sejumlah kompetensi dan indikatornya sebagai gambaran hasil belajar. Kegiatan pembelajaran berupaya mengubah masukan kepada peserta didik yang belum terdidik menjadi peserta didik yang terdidik, peserta didik yang belum memiliki pengetahuan menjadi peserta didik yang memiliki pengetahuan.

Sedangkan menurut Ahmad Susanto (2013: 4) bahwa pembelajaran adalah suatu aktivitas yang dilakukan seseorang dengan sengaja dalam keadaan sadar untuk memperoleh suatu konsep, pemahaman, atau pengetahuan baru sehingga memungkinkan seseorang terjadinya perubahan perilaku yang relatif tetap baik dalam berfikir, merasa, maupun dalam bertindak. Kata atau istilah belajar bukanlah suatu yang baru, sudah sangat dikenal secara luas, namun dalam pembahasan belajar ini masing-masing ahli memiliki pemahaman dan definisi yang berbeda-beda, walaupun secara praktis masing-masing kita sudah sangat memahami apa yang dimaksud dalam belajar tersebut.

Dari pendapat tersebut di atas, dapat dikatan bahwa pembelajaran adalah perubahan tingkah laku yang terjadi dari hasil latihan yang dilakukan secara sadar, bersifat fungsional, menetap, bersifat aktif dan positif berdasarkan atas latihan, bertujuan dan terarah serta mencakup keseluruhan aspek kepribadian manusia yang berlangsung sepanjang masa.

Pendidikan karakter menjadi isu sentral perkembangan pembelajaran di Indonesia. Segenap komponen pembelajaran dikaitkan dengan elemen pendidikan karakter disebabkan munculnya keluhan semakin menurunnya karakter masyarakat seiring pekembangan zaman. Secara umum pendidikan karakter menurut Triatmanto (2010) adalah suatu sistem penanaman nilai-nilai karakter kepada warga sekolah yang meliputi komponen pengetahuan, kesadaran atau kemauan, dan tindakan untuk melaksanakan nilai-nilai tersebut, baik terhadap Tuhan Yang Maha Esa (YME), diri sendiri, sesama, lingkungan, maupun kebangsaan sehingga menjadi manusia insan kamil. Penerapan pendidikan karakter memerlukan kerjasama seluruh komponen pembelajaran untuk keberhasilannya. Dalam pendidikan karakter di sekolah, semua komponen pendidikan (stakeholders) harus dilibatkan, termasuk komponenkomponen pendidikan itu sendiri.

Sri Anitah (2010: 4-6) mengemukakan bahwa media adalah setiap orang, bahan atau peristiwa yang dapat menciptakan kondiasi yang memungkinkan pelajar untuk menerima pengetahuan, ketrampilan dan sikap. Dalam konsep media pembelajaran, terdapat dua unsur, yaitu perangkat keras (hardware) dan materi atau bahan yang disebut perangkat lunak (software). Kemudian menurut Eclark dan Solomon (1986: 28) bahwa media dapat dipakai sebagai sarana eksternal dan bersamaan dengan faktor yang lain menyusun suatu tahapan kegiatan kognisi secara tepat, karena media merupakan bagian dari antisipasi yang diharapkan peserta didik. Apa yang diharapkan 
peserta didik atau kelas dengan media itu akan memberikan pengaruh yang sama terhadap proses seperti apa yang diharapkan dari media itu sendiri. Sedangkan menurut Azhar Arsyad (2013: 3) media adalah komponen sumber belajar atau wahana fisik yang mengandung materi instruksional di lingkungan peserta didik yang dapat merangsang peserta didik untuk belajar.

Mengenai media pembelajaran, Daryanto (2014: 6) berpendapat bahwa media pembelajaran adalah komponen integral dari sistem pembelajaran. Segala sesuatu yang dapat menyampaikan dan menyalurkan pesan dari sumber secara terencana sehingga tercipta lingkungan belajar yang kondusif dimana penerimanya dapat melakukan proses belajar secara efisien dan efektif. Sedangkan menurut Musfiqon (2012: 27) media pembelajaran sebagai alat bantu berupa fisik maupun nonfisik yang sengaja digunakan sebagai perantara antara guru dan peserta didik dengan utuh serta menarik peserta didik untuk belajar lebih lanjut.

Berdasarkan pendapat di atas dapat dikatakan bahwa media pembelajaran adalah segala sesuatu yang digunakan untuk menyampaikan dan menyalurkan pesan dari sumber secara terencana sehingga tercipta lingkungan yang kondusif. Penerimanya dapat melakukan proses belajar secara efektif dan efisien sehingga media pembelajaran dapat menarik perhatian peserta didik dalam proses pembelajaran baik di kelas maupun di luar kelas.

\section{METODE PENELITIAN}

Penelitian ini akan dilaksanakan di SD Negeri Bibisluhur 1 Surakarta dengan sumber informan adalah guru mata pelajaran IPS dan peserta didik. Tempat ini dipilih karena disamping muda terjangkau, baik dari segi biaya maupun waktu dan jarak. Lokasi ini pada dasarnya belum memanfaat dokumen-dokumen peninggalan sejarah tokoh lokal untuk dijadikan sebagai media pembelajaran IPS pada aspek materi sejarah.

Penelitian ini adalah penelitian pendidikan dengan pendekatan deskriptif kualitatif yang bertujuan untuk mengetahui sejauh mana efektivitas pembelajaran pendidikan karakter dengan menggunakan media kartun dan gambar tokoh lokal pada peserta didik SD Negeri Bibisluhur 1 Surakarta. Di samping itu, data yang dikumpulkan berupa kata-kata dan bukan angka-angka, di mana semua data yang dikumpulkan kemungkinan menjadi kunci terhadap objek yang akan diteliti. Kondisi objek sama sekali tidak dijamah oleh perlakuan (treatment) yang dikendalikan secara ketat atau sepenuhnya oleh peneliti seperti halnya di dalam penelitian eksperimental (Sutopo, 2006: 37). Di sini peneliti berfungsi sebagai penggali informasi pada saat berlangsungnya kegiatan penelitian. Strategi penelitian yang digunakan adalah studi kasus tunggal terpancang, sebagaimana pendapat Yin yang dikutip Sutopo (2006: 39) disebut embedded research. Kasus tunggal karena sasaran penelitian ini pada satu kasus yaitu efektivitas pembelajaran pendidikan karakter dengan menggunakan media kartun dan gambar tokoh lokal pada peserta didik sekolah dasar. Terpancang karena masalah sudah ditentukan terlebih dahulu sebelum kegiatan penelitian ini dilakukan. 
Data penelitian ini diperoleh dari: (1) Tempat dan peristiwa yaitu kegiatan pembelajaran di SD Negeri Bibisluhur 1 Surakarta. Dari sumber data ini akan diperoleh informasi tentang efektivitas pembelajaran pendidikan karakter dengan menggunakan media kartun dan gambar tokoh lokal; (2) Dokumen, yaitu dokumen berupa buku-buku pelajaran, media pembelajaran yang digunakan oleh guru, dan laporan hasil evaluasi belajar peserta didik, dan (3) Informan, yaitu terdiri dari guru dan peserta didik kelas 5 SD Negeri Bibisluhur 1 Surakarta. Dari sumber data ini akan diperoleh informasi tentang: (a) media pembelajaran yang digunakan guru dalam pembelajaran pendidikan karakter, dan (b) keefektivan media kartun dan gambar tokoh lokal dalam meningkatkan pembelajaran pendidikan karakter. Untuk memperoleh data dilakukan dengan: (1) Observasi saat pembelajaran berlangsung di kelas; (2) Analisis dokumen, dan (3) Wawancara mendalam. Kemudian dalam upaya memperoleh validitas data dilakukan dengan trianggulasi data/sumber dan metode. Sedangkan teknik analisis data dilakukan secara bersama dengan pengumpulan data secara interaktif dengan model siklus, di mana dalam analisis data ada tiga komponen analisis, yaitu reduksi data, sajian data dan verifikasi atau penarikan simpulan.

\section{HASIL PENELITIAN}

\section{Deskripsi Latar}

\section{a. Kondisi Umum Sekolah}

Berdasarkan lingkup wilayah yang telah dirancangan dalam penelitian ini, sehingga lokasi yang dipilih adalah SD Negeri Bibiluhur 1 Surakarta, maka dapat disajikan kondisi sekolah secara umum terutama pada aspek pembelajaran. Aspek pembelajaran yang dikaji adalah pembelajaran pendidikan karakter yang difokuskan pada efektivitas pembelajaran pendidikan karakter dengan menggunakan media pembelajaran kartun dan gambar tokoh lokal.

Dari hasil observasi dan wawancara dengan guru dan peserta didik kelas 5 SD Negeri Bibisluhur 1 Surakarta, bahwa dalam kegiatan belajar mengajar guru masih menggunakan metode ceramah dan pemberian tugas. Melaui metode mengajar yang digunakan ini, dapat mengakibatkan peserta didik kurang aktif dan tidak memperhatikan guru pada saat penyampaian materi pembelajaran sehingga berdampak pada kesulitan peserta didik menerima isi materi pembelajaran. Di samping itu, peserta didik merasa bosan dan mengantuk saat kegiatan belajar mengajar berlangsung. Kondisi ini berpengaruh terhadap sikap peserta didik yang dinilai masih rendah sebagaimana diskripsi sikap pada mata pelajaran PKn.

Sementara kondisi umum SD Negeri Bibisluhur 1 Surakarta berada di tengah pemukiman penduduk dan jarak tempuh dari tempat tinggal peserta didik tidak terlalu jauh. Bila dilihat dari tata laksana dan pengelolaan manajemen sekolah, maka SD Negeri Bibisluhur 1 Surakarta tergolong cukup maju dan memenuhi ketentuan sebagai penyelenggara satuan pendidikan yaitu terdiri dari 6 rombongan belajar yaitu kelas 1 
sampai kelas 6 dengan 1 orang kepala sekolah, 6 orang guru kelas, 1 orang guru seni tari, 1 orang guru olah raga, dan 1 orang tata usaha.

Selanjutnya, dalam hal kegiatan proses pembelajaran terutama materi pembelajaran yang mengarah pada penanaman karakter peserta didik, guru senantiasa berupaya semaksimal mungkin untuk dapat mewujudkan capaian dan target pembelajaran yang telah ditetapkan. Dalam pandangan lain bahwa perkembangan prilaku dan karakteristik anak secara umum dapat dikatakan bahwa tidak ada seorangpun yang menginginkan pergeseran karakter anak atau peserta didiknya. Terlebih lagi seorang guru yang selalu berusaha mengawasi dan mengontrol perkembangan karakteristik anak didiknya karena bagi mereka bahwa karakter merupakan persoalan penting yang harus dipertahankan dan ditanamkan dalam diri peserta didik guna menjadi bekal hidup mereka pada masa mendatang.

\section{b. Efektivitas Pembelajaran Pendidikan Karakter Dengan Menggunakan Media Kartun dan Gambar Tokoh Lokal}

Pembelajaran adalah sebuah proses komunikasi antara pembelajar, pengajar dan bahan ajar. Komunikasi tidak akan berjalan tanpa bantuan sarana penyampai pesan atau media. Dalam proses belajar, bentuk -bentuk stimulus yang datang dari sumber belajar (termasuk karikatur) bisa dipergunakan sebagai media diantaranya adalah hubungan atau interaksi manusia; realia, gambar bergerak atau tidak; tulisan dan suara yang direkam. Sebagai seorang pendidikan, maka guru mengupayakan agar peserta didik mengetahui konsep nilai pendidikan karakter.

Untuk mengetahui tingkat kepahaman peserta didiknya terhadap pendidikan karakter, maka guru dapat melakukannya melalui tes awal dengan metode tanya jawab sesuai dengan konsep yang menjadi tujuan pembelajaran. Pendidikan karakter dapat dilakukan dengan membuat variasi media pembelajaran dan kemudian menugaskan peserta didiknya untuk mempraktikkan materi yang sudah diajarkan guru. Terkait penanaman karakter pada peserta didik, guru harus mampu membuat variasi materi mapel, misalnya dengan menggunakan media gambar tokoh lokal khusus materi sejarah. Walaupun di satu sisi guru telah melaksanakan pembelajaran yang mengarah pendidikan karakter, namun di sisi lain jarang sekali materinya mencantum karakteristik tokoh-tokoh lokal apalagi lebih jauh memperkenalkan peristiwa masa lalu yang pernah terjadi didaerahnya.

Media pembelajaran kartun adalah penggambaran dalam bentuk lukisan atau karikatur tentang orang, gagasan-gagasan atau situasi yang didesain untuk memepengaruhi opini peserta didik. Kartun sebagai alat bantu mempunyai manfaat penting dalam pembelajaran, terutama dalam menjelaskan rangkaian isi bahan dalam satu urutan logis atau mengandung makna yang cukup unik untuk mengkomunikasikan gagasangagasan dalam menyampaikan pesan materi pembelajaran pada peserta didik. Penggunaan media pembelajaran kartun mengandung penjelasan dari pengertian simbolis. 
Sedangkan media pembelajaran gambar tokoh lokal merupakan media pembelajaran dalam bentuk gambar yang bermuatan edukasi dengan obyek manusia atau benda. Gambar tokoh lokal yang ditampilkan dapat menimbulkan pesan yang bersifat membesar-besarkan (exaggerate) atau sebaliknya memupus (distort) karakter seseorang atau sesuatu untuk menumbuhkan kesan positif pada peserta didik sehingga tertanam semangat kecintaan terhadap kearifan lokal daerahnya. Media pembelajaran gambar tokoh lokal dapat dijadikan alat bantu pembelajaran dalam upaya menanamkan karakter positif dan dapat dibuat dalam bentuk gambar pahlawan atau tokoh-tokoh lainnya. Media gambar tokoh lokal termasuk jenis media grafis atau media visual, karena hanya dapat dicerna melalui indera penglihatan. Selain itu juga media gambar tokoh lokal mampu menimbulkan rangsangan untuk berefleksi dan berpikir kreatif. Di sisi lain, media gambar tokoh lokal merupakan alat atau perangkat pembelajaran yang dapat mendeskripsikan seorang yang memiliki sejarah atau hal menarik yang patut dijadikan contoh dan teladan bagi perbaikan karakter peserta didik.

Untuk mencapai keberhasilan atau pencapaian target pembelajaran pendidikan karakter melalui materi pembelajaran sejarah dalam upaya menamkan karakter kecintaan terhadap kearifan lokal dan peristiwa sejarah di daerahanya lebih efektif menggunakan media pembelajaran gambar tokoh lokal sebagaimana data sebagai hasil penelitian yang dilakukan pada peserta didik kelas 5 SD Negeri Bibisluhur 1 Surakata. Secara umum ada 5 karakter yang perlu dikembangkan pada peserta didik sekolah dasar, yaitu: religius, cinta kebersihan dan lingkungan, sikap jujur, sikap peduli, dan rasa cinta tanah air (sikap nasionalisme dan patriotisme).

\section{Sajian Data}

Untuk menjelaskan efektivitas pembelajaran pendidikan karakter dengan menggunakan media kartun dan gambar tokoh lokal di tingkat sekolah dasar dapat dilihat pada sajian data di bawah ini:

1. Media pembelajaran yang digunakan guru dalam pembelajaran pendidikan karakter pada peserta didik SD Negeri Bibisluhur 1 Surakarta.

Dari hasil wawancara dengan guru kelas 5 SD Negeri Bibisluhur 1 Surakarta bahwa untuk melihat efektivitas pembelajaran pendidikan karakter dengan membandingkan media pembelajaran kartun dan gambar tokoh lokal belum pernah dilakukan. Dalam hal penanaman pendidikan karakter pada peserta didik selama ini guru hanya memberikan contoh-contoh tentang perjuangan para pahlawan dan belum pernah menggunakan media pembelajaran dalam bentuk gambar serta selalu dominan menggunakan metode ceramah. Adapun media pembelajaran yang digunakan guru dalam menyampaikan materi pembelajaran adalah berupa media yang bersifat umum sebagaimana tercantum di dalam silabus dan rencana pelaksanaan pembelajaran (RPP) serta buku pegangan guru yang ditentukan secara nasional. Guru belum pernah membuat skenario pembelajaran atau kreativitas lain yang berkaitan dengan media sebagai alat pedukung penyampaian pesan materi pembelajaran terutama dalam upaya penanaman karakter positif pada peserta didik. 
Dari hasil pengamatan pada saat pelaksanaan kegiatan pembelajaran di kelas, setelah guru memberikan penjelasan materi pembelajaran kemudian guru meminta peserta didik untuk bertanya tentang isi materi yang disampaikan, apakah peserta didik sudah mengerti dan memahaminya atau belum. Langkah berikutnya, guru meminta peserta didik untuk membaca ulang dan memahami secara perlahan-lahan isi materi yang telah diterangkannya dari halaman pertama sampai terakhir dengan menggunakan buku pegangan siswa. Kemudian guru meminta peserta didiknya untuk menjelaskan isi materi yang telah dibaca tadi secara bergiliran satu persatu. Ketika peserta didik salah dalam menjelaskannya, maka guru memperbaiki dan meluruskannya serta memberikan contoh nyata, kemudian guru memerintahkan peserta didiknya memberikan penjelasan ulang dari materi tersebut seperti apa yang sudah dicontohkannya. Kemudian langkah selanjutnya, guru memberikan contoh secara langsung kepada peserta didik berkaitan dengan pesan isi materi pembelajaran tadi dengan maksud agar mereka ingat akan kesalahan yang dilakukannya.

Sementara dari hasil wawancara dengan peserta didik kelas 5 SD Negeri Bibisluhur 1 Surakarta, mereka menuturkan bahwa media yang dipergunakan guru dalam menyampaikan materi pembelajaran yang mengarah pada pendidikan karakter masih menggunakan media yang bersifat umum sebagaimana yang telah tertera di dalam silabus dan buku pegangan guru. Dalam menyajikan meteri pembelajaran terutama yang menjurus pada penanaman karakter dan kecintaan terhadap kearifan lokal, guru tidak menggunakan media pembelajaran yang sesuai dengan isi materi misalnya menggunakan media gambar tokoh lokal dan peninggalan-peninggalan sejarah di daerah. Penyampaian meteri pembelajaran oleh guru masih belum maksimal dan terlalu monoton menggunakan metode ceramah dan pemberian tugas, akan tetapi jarang menggunakan media pembelajaran.

Realita ini dapat dikatakan masih menggunakan pola pembelajaran tradisonal dimana proses pembelajaran biasanya masih berlangsung di dalam kelas dengan pendekatan teacher centered dan guru lebih banyak berperan sebagai pengatur jadwal sehingga kegiatan belajar mengajar hanya bisa berlaku pada waktu dan tempat yang telah ditentukan. Padahal untuk menyampaikan pesan nilai pendidikan karakter pada peserta didik sangat baik dilakukan melalui pemanfaatan media gambar tokoh atau peninggalan sejarah daerah. Peserta didik berharap agar senantiasa guru lebih terampil dalam memilih media pembelajaran dan disesuaikan dengan materi sebelum pelaksanaan kegiatan belajar mengajar agar lebih terarah dan peserta didik lebih termotivasi.

Penggunaan media pembelajaran memiliki tujuan untuk memberikan motivasi dan semangat belajar kepada peserta didik. Di samping itu, media pembelajaran juga dapat merangsang peserta didik untuk mengingat apa yang telah dipelajarinya selain dapat memberikan rangsangan pada meteri pembelajaran yang akan dipelajari berikutnya. Media pembelajaran yang baik juga dapat meningkatkan keaktifan peserta didik dalam memberikan tanggapan, umpan balik dan juga mendorong peserta didik untuk melakukan praktek-praktek isi materi pembelajaran dengan benar. Selain itu, media pembelajaran juga memiliki pengaruh besar terhadap terciptanya kegiatan belajar mengajar yang menyenangkan bagi peserta didik yang senantiasa akan 
berdampak pada kualitas pembelajaran sebab media pembelajaran dapat membantu peserta didik untuk memahami materi yang sulit dengan memberikan pemahaman yang lebih mudah dan jelas. Penggunaan media pembelajaran sangat diperlukan dalam kaitannya dengan peningkatan mutu dan kualitas pendidikan karena dapat membantu guru dalam proses penyampaian pesan-pesan materi pembelajaran kepada peserta didiknya.

2. Keefektivan media kartun dan gambar tokoh lokal dalam meningkatkan pembelajaran pendidikan karakter di SD Negeri Bibisluhur 1 Surakarta.

Media pembelajaran kartun merupakan media yang cukup unik bila dipergunakan dalam mengkomunikasikan gagasan dan penyampaian pesan materi pembelajaran pada peserta didik. Media kartun adalah penggambaran dalam bentuk lukisan atau karikatur tentang orang, gagasan-gagasan atau situasi yang didesain untuk memepengaruhi opini peserta didik. Dapat dikatakan bahwa media pembelajaran kartun bisa dimanfaatkan sebagai alat bantu yang sederhana dalam kegiatan pembelajaran, terutama dalam memaparkan seluruh rangkaian isi materi pembelajaran secara runtut, logis dan bermakna. Selanjutnya, media pembelajaran kartun ini dapat dibuat oleh guru yang disesuaikan dengan karakteristik materi pembelajaran ataupun dengan memberikan tugas pada peserta didik untuk membuatnya. Hal ini dilakukan bertujuan untuk melatih dan menumbuhkan kreatifitas peserta didik dalam menghungkan, memahami, dan menganalisis media gambar dengan materi pembelajaran. Selain itu juga, diharapkan bahwa para peserta didik membuat kartun untuk menumbuhkan minat misalnya dalam promosi kebersihan sekolah, rajin belajar, kedisiplinan, dan kerapian.

Sedangkan media pembelajaran gambar tokoh lokal merupakan media yang dapat digunakan untuk mendeskripsikan seorang yang memiliki sejarah perjuangan (patriotisme) masa lalu yang patut diungkapkan melalui sebuah gambar dan ditampilkan dalam kegiatan pembelajaran. Media pembelajaran gambar tokoh lokal juga memiliki fungsi ganda yaitu sebagai media yang digunakan untuk mempengaruhi opini publik dalam bidang sosial maupun politik dan sebagai alat penyampaian pesan materi pembelajaran kepada peserta didik. Dalam hal keberfungsiannya sebagai alat untuk menyajikan pesan materi pembelajaran, maka seyogyanya peserta didik sudah cukup mengenal sebagian atau keseluruhan gambar tokoh lokal yang ditampilkan, sehingga akan membantu peserta didik mendapatkan gambaran yang jelas terhadap setiap obyek yang ada dalam gambar tersebut serta dapat meniru dan menjadi contoh dalam keseharian mereka. Di sisi lain bahwa penggunaan media pembelajaran gambar tokoh lokal mempunyai tujuan untuk memberikan motivasi dan mampu merangsang semangat belajar peserta didik. Oleh sebab itu, dapat dikatakan bahwa media pembelajaran gambar tokoh lokal merupakan salah satu komponen strategi penyampaian yang dapat dimuati pesan materi pembelajaran yang akan disampaikan kepada peserta didik, baik berupa manusia, alat, maupun bahan materi pembelajaran.

Berdasarkan hasil wawancara dengan guru dan peserta didik kelas 5 SD Negeri Bibisluhur 1 Surakarta, bahwa bila melihat keefektivan pemanfaatan media dalam meningkatkan pembelajaran pendidikan karakter peserta didik, maka dapat dikatakan 
lebih efektif menggunakan media pembelajaran gambar tokoh lokal dibandingkan dengan media pembelajaran kartun. Hal ini dimungkinkan dapat tercapainya target pembelajaran karena media gambar tokoh lokal dapat secara langsung dipaparkan kepada peserta didik secara visual yang sertai penjelasan. Media gambar tokoh lokal dilengkapi dengan biografinya yang disajikan dapat memberikan pesan moral dan jiwa patritisme serta kedisiplinan kepada peserta didik. Contoh-contoh yang ditunjukkan dari seluruh aktivitas hidup termasuk perjuangan dan pengorbanan para tokoh lokal tersebut juga menjadi motivasi bagi peserta didik dalam proses perkembangan karakter dan moral mereka. Pesan moral dalam media pembelajaran gambar tokoh lokal dapat menumbuhkan semangat juang peserta didik dalam belajar sehingga dapat menggeser norma dan nilai-nilai yang tertanam sejak lama dan melekat pada diri mereka seperi rasa malas, tidak memperhatikan guru dalam kegiatan pembelajaran, dan bahkan sering ribut dalam kelas. Oleh karena itu, kondisi ini baik secara langsung maupun tidak langsung akan mampu menanamkan sikap dan karakter positif pada peserta dan didik yang akhirnya gurupun bergairah dan bersemangat dalam menyampaikan materi pembelajaran.

Perkembangan penggunaan media dalam menyampaikan materi pembelajaran cukup signifikan dalam membantu upaya guru membuat skenario dan variasi di setiap kegiatan pembelajaran sehingga lebih menarik minat dan motivasi belajar peserta didik. Lama kelamaan upaya seperti ini baik secara langsung atau tidak langsung akan mempengaruhi pikiran seseorang baik guru maupun peserta didik sehingga dapat mempermudah munculnya pergeseran nilai dan norma dalam kehidupan masyarakat. Dalam hal ini, guru sangat berperan penting untuk membelajarkan dan mengendalikan peserta didiknya sejak dini terhadap upaya pemanfaatan media gambar tokoh lokal sehingga muncul rasa kecintaan terhadap daerahnya, memiliki jiwa mandiri, sikap patriotisme, dan kedisplininan dimana pada akhirnya terwujud karakter dan moral yang baik.

\section{Pokok Temuan}

1. Media pembelajaran yang digunakan guru dalam pembelajaran pendidikan karakter pada peserta didik di SD Negeri Bibisluhur 1 Surakarta adalah bahwa guru belum pernah melakukan pembandingan antara media pembelajaran kartun dan gambar tokoh lokal untuk melihat efektivitas pembelajaran pendidikan karakter. Dalam hal penanaman pendidikan karakter pada peserta didik selama ini guru hanya memberikan contoh-contoh tentang perjuangan para pahlawan dan belum pernah menggunakan media pembelajaran dalam bentuk gambar serta selalu dominan menggunakan metode ceramah. Adapun media pembelajaran yang digunakan guru dalam menyampaikan materi pembelajaran adalah berupa media yang bersifat umum sebagaimana tercantum di dalam silabus dan rencana pelaksanaan pembelajaran (RPP) serta buku pegangan guru yang ditentukan secara nasional. Guru belum pernah membuat skenario pembelajaran atau kreativitas lain yang berkaitan dengan media sebagai alat pedukung penyampaian pesan materi pembelajaran terutama dalam upaya penanaman karakter positif pada peserta didik. Melihat situasi dan kondisi pembelajaran yang dilaksanakan oleh guru maka tentunya akan berakibat pada konsentrasi dan perhatian peserta didik pada saat pembelajaran berlangsung kurang 
maksimal. Keberhasilan dan ketercapaian target dalam suatu pelaksanaan kegiatan pembelajaran sangat ditentukan oleh konsentrasi dan perhatian peserta didik. Dalam menyajikan meteri pembelajaran terutama yang menjurus pada penanaman karakter dan kecintaan terhadap kearifan lokal, guru tidak menggunakan media pembelajaran yang sesuai dengan isi materi misalnya menggunakan media gambar tokoh lokal dan peninggalan-peninggalan sejarah di daerah. Penyampaian meteri pembelajaran oleh guru masih terlalu monoton menggunakan metode ceramah dan pemberian tugas, akan tetapi jarang menggunakan media pembelajaran. Padahal untuk menyampaikan pesan nilai pendidikan karakter pada peserta didik sangat baik dilakukan melalui pemanfaatan media gambar tokoh atau peninggalan sejarah daerah.

2. Keefektivan media kartun dan gambar tokoh lokal dalam meningkatkan pembelajaran pendidikan karakter di SD Negeri Bibisluhur 1 Surakarta, bahwa setelah guru melakukan uji coba dengan membandingkan media kartun dan gambar tokoh lokal dalam melihat keefektivan pemanfaatannya guna meningkatkan pembelajaran pendidikan karakter peserta didik, maka dapat dikatakan lebih efektif menggunakan media pembelajaran gambar tokoh lokal dibandingkan dengan media pembelajaran kartun. Hal ini dimungkinkan dapat tercapainya target pembelajaran karena media gambar tokoh lokal dapat secara langsung dipaparkan kepada peserta didik secara visual yang sertai penjelasan. Media gambar tokoh lokal dilengkapi dengan biografinya yang disajikan dapat memberikan pesan moral dan jiwa patriotisme serta kedisiplinan kepada peserta didik. Pesan moral dalam media pembelajaran gambar tokoh lokal dapat menumbuhkan semangat juang peserta didik dalam belajar sehingga dapat menggeser norma dan nilai-nilai yang tertanam sejak lama dan melekat pada diri mereka seperi rasa malas, tidak memperhatikan guru dalam kegiatan pembelajaran, dan bahkan sering ribut dalam kelas. Oleh sebab itu, dapat dikatakan bahwa media pembelajaran gambar tokoh lokal merupakan salah satu komponen strategi penyampaian yang dapat dimuati pesan materi pembelajaran yang akan disampaikan kepada peserta didik, baik berupa manusia, alat, maupun bahan materi pembelajaran. Media pembelajaran gambar tokoh lokal dalam proses pembelajaran dapat dimanfaatkan sebagai salah satu cara yang dapat mengarahkan perhatian peserta didik sehingga menumbuhkan motivasi untuk belajar dan materi pembelajaran yang disampaikan guru akan lebih jelas dan cepat dipahami, namun yang tidak kalah penting adalah ketercapaian target pembelajaran yang telah ditetapkan.

\section{CONCLUSION}

Untuk melihat efektivitas pembelajaran pendidikan karakter dengan membandingkan media pembelajaran kartun dan gambar tokoh lokal belum pernah dilakukan oleh guru. Dalam hal penanaman pendidikan karakter pada peserta didik selama ini guru hanya memberikan contoh-contoh tentang perjuangan para pahlawan dan belum pernah menggunakan media pembelajaran dalam bentuk gambar serta selalu dominan menggunakan metode ceramah. Adapun media pembelajaran yang digunakan guru dalam menyampaikan materi pembelajaran adalah berupa media yang bersifat umum 
sebagaimana tercantum di dalam silabus dan RPP serta buku pegangan guru yang ditentukan secara nasional. Guru belum pernah membuat skenario pembelajaran atau kreativitas lain yang berkaitan dengan media sebagai alat pedukung penyampaian pesan materi pembelajaran terutama dalam upaya penanaman karakter positif pada peserta didik.

Mengamati keefektivan pemanfaatan media dalam meningkatkan pembelajaran pendidikan karakter peserta didik, maka dapat dikatakan lebih efektif menggunakan media pembelajaran gambar tokoh lokal dibandingkan dengan media pembelajaran kartun. Hal ini dimungkinkan dapat tercapainya target pembelajaran karena media gambar tokoh lokal dapat secara langsung dipaparkan kepada peserta didik secara visual yang sertai penjelasan. Media gambar tokoh lokal dilengkapi dengan biografinya yang disajikan dapat memberikan pesan moral dan jiwa patritisme serta kedisiplinan kepada peserta didik. Contoh-contoh yang ditunjukkan dari seluruh aktivitas hidup termasuk perjuangan dan pengorbanan para tokoh lokal tersebut juga menjadi motivasi bagi peserta didik dalam proses perkembangan karakter dan moral mereka.

\section{SARAN}

Untuk mewujudkan ketercapaian pelaksanaan kegiatan pembelajaran pendidikan karakter dengan memanfaatkan media pembelajaran pada peserta didik di tingkat sekolah dasar sangat membutuhkan perhatian dari berbagai pihak, seperti:

1. Pemerintah dalam hal ini Dinas Pendidikan agar terus berupaya untuk meningkatkan ketersediaan berbagai fasilitas penunjang pembelajaran di sekolah termasuk ketersediaan media pembelajaran dan melakukan pengawasan secara kontinu terhadap manajemen sekolah.

2. Guru agar secara kontinu dan terus menerus melakukan inovasi dan membuat variasi media pembelajaran yang dipergunakan untuk memghubungkan pesan materi pembelajaran dengan peserta didik, terutama dalam hal pembelajaran penanaman pendidikan karakter. Dengan memanfaatkan media pembelajaran bervariasi maka senantiasa akan menumbuhkan semangat dan motivasi belajar peserta didik. Perlu diperhatikan, bahwa pemilihan media pembelajaran harus terlebih dahulu disesuaikan dengan karakteristik materi pembelajaran dan karakteristik peserta didik. 


\section{REFERENCES}

Abdul Majid, 2013. Strategi Pembelajaran. Bandung: Remaja Rosdakarya.

Ahmad Susanto, 2013. Teori Belajar dan Pembelajaran di Sekolah Dasar. Jakarta: Prenada Group.

Barnawi \& M. Arifin, 2012.Strategi \& Kebijakan Pembelajaran Pendidikan Karakter. Yogyakarta: Ar-ruzz Media.

Daryanto.2014. Pembelajaran Tematik, Terpadu, Terintegrasi Kurikulum 2013. Yogyakarta: Gava Media.

Departemen Pendidikan dan Kebudayaan, 2013, Kurikulum 2013Pendidikan Dasar: PedomanPengembangan Silabus dan Penilaian, Jakarta: Direktorat JenderalPendidikan Dasar dan Menengah Direktorat Pendidikan Dasar.

Dharma Kesuma, M.Pd., dkk. 2011. Pendidikan Karakter: Kajian Teori dan Praktek di Sekolah. Bandung: PT. Remaja Rosdakarya.

Dhurorudin, dkk. 2005. Konflik Antar Elit Politik Lokal Dalam Pemilihan Kepala Daerah. Jakarta: Pustaka Pelajar.

Dimyati dan Mudjiono. 2006. Belajar dan Pembelajaran. Jakarta: PT. Rineka Cipta.

Gagne, Robert M, Marcy Perkins Driscoll, 1989, Essential of Learning for Introduction, New Yersey: Prentice Hall, Inc.

Ida Zusnani. 2012. Manajemen Pendidikan: Berbasis Karakter Bangsa. Jakarta: Tugu Publisher

LPPM UNISRI.2013. Panduan Penelitian dan Pengabdian Pada Massyarakat. Surakarta. Universitas Slamet Riyadi.

Legge, John D. 2001. Sukarno; Biografi Politik. Jakarta: Sinar Harapan.

Moh. Zaiful Rosyid, dkk. 2019. Ragam Media Pembelajaran; Visual, Audio Visual, Interactive Video, Power Point, E-Learning. Malang: CV. Literasi Nusantara Abadi

Sugiyono. 2014. Metode Penelitian Bisnis (Pendekatan Kuantitatif, Kualitatif, dan $R \& D$ ). Bandung: CV Alfabeta.

Suwarno, P.J. 1994. Hamengku Buwono IX dan Sistem Birokrasi Pemerintahan. Yogyakarta 1942-1974; Sebuah Tinjauan Historis. Yogyakarta: Kanisius.

Soetomo Siswokartono, W.E. 2006. Sri Mangkunegara IV Sebagai Penguasa dan Pujangga 1853-1881. Semarang: CV. Aneka Ilmu.

Sri Anitah, 2010. Media Pembelajaran. Surakarta: Yuma Pustaka.

Sutopo, HB, 2006, Metode Penelitian Kualitatif: Dasar Teori dan Terapannya dalam Penelitian, Surakarta: Universitas Sebelas Maret Press.

Trianto. 2010. Model Pembelajaran Terpadu. Jakarta: PT. Bumi Aksara.

Triatmanto. 2010. "Tantangan Pendidikan Karakter di Sekolah". Dalam Cakrawala

Pendidikan, Vol. 1, No. 3, 2010. 